\title{
On the elemental composition estimation of some herbal species of calcareous steppes and its bioindication prospects
}

\author{
Nataly Prokhorova*, Rezida Sarvarova, Yuly Makarova, Sergey Bugrov, Oxana Kuzovenko \\ Samara National Research University, 443086 Moskowskoye Shosse, 34, Samara, Russian Federation
}

\begin{abstract}
On the territory of our country, in foreign Europe, in North America, in some regions there are outcrops calcareous rocks. The high endemism and the same of rare plant species concentration are characteristic features of such landscapes. The results of elemental composition primary assessment of aboveground and underground organs of three plant species from calcareous biotopes of Samara region are given. Three species were chosen for studies: obligate calcephite Gypsophila jusepczukii Ikonn., calcephilic Hedysarum grandiflorum Pall. (both included in the Red Book of Samara Region), Reseda lutea L., a ruderal species. For the quantitative analysis of the content of metals in the stems, leaves, flowers, and roots of these plants, the method of spectrometry with inductively coupled plasma was used. It was shown that the effective barrier function of roots in relation to most of the analyzed elements is characteristic of calcephilous (Hedysarum) and calcephytic (Gypsophila) plant species, but not for Reseda lutea. To a certain extent, the stem tissues play a barrier biogeochemical role in Reseda. A general biogeochemical feature of these species, especially pronounced for Reseda, is expressed in increased Se accumulation in aboveground organs.
\end{abstract}

\section{Introduction}

Massive outcrops of calcium-containing rocks in sediments of certain geological epochs are presented on different continents and are localities where special conditions of soil formation develop and specific plant communities - calcareous floras - are formed. On the territory of our country, in foreign Europe, in North America, some regions are known where there are outcrops of chalk and other calcareous rocks [1-3]. In the complex of these conditions, the following are distinguished: absence or weak soils development; substrate mobility; specific microclimate of these habitats; chemical and physical characteristics of chalk as a substrate. The combination of such features forms an edaphic specificity of the calcareous outcrops, which is reflected in the life forms composition of plants growing here, adapted to concrete types of habitats. Among the most common habitats types of chalk outcrops, there are taluses, dense layers of bedrock, overgrown outcrops, and cones of gully outcrops [2].

\footnotetext{
* Corresponding author: natali.prokhorova.55@mail.ru
} 
Among the most important tasks of ecology is the determination of the species diversity of ecosystems and the ecological role that each specific species plays in them. The endemic complex of species is widely represented among the characteristic and rare plants of the calcareous uplands and outcrops, which are characterized by a certain constancy of ecological conditions. In general, high endemism and the same of rare plant species concentration are characteristic features of the Eurasia calcareous outcrops, which is associated with the historical past of the considered ecotopes, the characteristics of the substrate and the locality of habitats that do not promote new taxons to spread and mix themselves with similar forms in other territories [3]. Plants of chalk outcrops are usually distinguished by a rather clearly pronounced xeromorphic structure of aboveground organs with a complex of specific features (pubescence, waxy bloom, smaller leaves, often with a silvery sheen, etc.). These plants have a low competitive ability in relation to common steppe species on chernozems, but within the calcareous outcrops, calcephytes have no competitors. The composition of the ecobiomorphs of the calcareous floras show that they are characterized by special types of plants life forms. Among them, there are semi-shrubs, which are most fully represented among obligate calcephytes, as well as tap-root perennials, the vast majority of which are facultative calcephytes with an insignificant participation of rhizome perennials. These morphological features distinguish the calcareous flora from the zonal steppe and forest-steppe flora. A high proportion of rhizome plants is characteristic of the calciphytic-petrophytic variant of meadow steppes and reflects more mesophytic conditions of their existence [4].

The study of important differences in the structure and metabolism of calcephytes is of great interest and must be carried out necessarily for local flora species. The plants of chalk outcrops can attract special attention, taking into account the prospects for their preservation in culture, for example, in the collections of botanical gardens, or when grown in various objects of landscaping. In particular, such species that are undemanding to soil fertility and tolerate excess calcium can be used in the disturbed lands reclamation withdrawn from exploitation quarries, the vicinity of industrial facilities, roadsides of transport routes, etc. The specific composition of the phytomass is also valuable, especially as for species with medicinal use prospects $[5,6]$.

For scientific and practical purposes, important indicators are the chemical composition of plant biomass, especially the elemental composition of their individual organs: stems, leaves, flowers, roots. The accumulation of inorganic substances (ash component) by plants is associated both with the need to bind ions arriving from the outside in the phytomass (for example, in the form of calcium oxalate crystals in vacuoles), and with the involvement of a number of chemical elements in the metabolism of a higher plant as components of colloidal systems (for example, $\mathrm{K}^{+}$), active centers of enzymes (for example, $\mathrm{Fe}^{2+} / \mathrm{Fe}^{3+}$, $\left.\mathrm{Cu}^{2+}, \mathrm{Zn}^{2+}, \mathrm{Ni}^{+}, \mathrm{Co}^{2+}\right)$, chlorophyll molecules $\left(\mathrm{Mg}^{2+}\right)$, etc. [7]. Of particular interest are data on the accumulation of heavy metals by plants of various biotopes, including chalk outcrops, for assessing polymetallic pollution of the environment and obtaining an ecologically clean phytomass of wild plants used by humans $[5,6]$. The purpose of this study was the primary assessment of the elemental composition of aboveground and underground organs of some grasses from calcareous biotopes of Samara region.

\section{Research methodology}

Field studies and sampling for polyelement analysis were carried out in July 2020 in the biotopes of the stony steppe in the vicinity of the village of Podvalye in the Shigonsky district of the Samara region (a regional natural monument). Three species were chosen for biogeochemical studies: the obligate calciphyte Gypsophila jusepczukii Ikonn., calciphilic species Hedysarum grandiflorum Pall. (both species are included in the Red Book of the 
Samara Region), Reseda lutea L., which has features of a ruderal species. For the quantitative analysis of the 15 elements content in stems, leaves, flowers, and roots of these plants, the method of spectrometry with inductively coupled plasma was used [8].

\section{Results and discussion}

It is known that the ash component accumulation in plants under normal habitat conditions reflects the level of tissues metabolic activity - the leaf mesophyll usually has the highest ash content, the lowest is in wood, which consists mainly of conductive and mechanical tissues without living protoplasts, there are noticeable differences between plant species [7].

In the studied plant samples, the content of 15 elements was analyzed, including 13 metals (Ca, Mn, Cr, V, Co, Ni, Cu, Zn, Pb, Cd, Fe, Ar, Rb) and 2 metalloids (As, Se). The general biogeochemical differences of the studied plants from the average values for the herbaceous meadow and steppe species of the region are presented in Table 1. The average indicators of herbaceous species (75 species), in comparison with 3 analyzed species growing on the calcareous outcrops, accumulated most elements in the aboveground phytomass more actively, except for $\mathrm{Ca}, \mathrm{Sr}$ and Se. The concentration of the latter, on the contrary, is noticeably higher in the phytomass of Gypsophila (Ca, Sr, Se) and Reseda (Ca, $\mathrm{Sr}$, especially $\mathrm{Se})$.

Table 1. The average content of the studied elements in the total aboveground phytomass of herbaceous plants of the Samara region ( 75 species) and herbaceous species from the stony steppe of Podvalye, Samara region ( $\mathrm{mg} / \mathrm{kg}$ of air dry mass)

\begin{tabular}{|l|c|c|c|c|}
\hline $\begin{array}{c}\text { Chemical } \\
\text { elements }\end{array}$ & $\begin{array}{c}\text { Average content (for 75 } \\
\text { species, mg/kg) }\end{array}$ & $\begin{array}{c}\text { Gypsophila } \\
\text { jusepczukii }\end{array}$ & $\begin{array}{c}\text { Hedysarum } \\
\text { grandiflorum }\end{array}$ & Reseda lutea \\
\hline $\mathrm{Ca}$ & 11652.00 & 20616.67 & 9598.00 & 12140.33 \\
\hline $\mathrm{Mn}$ & 93.88 & 9.73 & 15.37 & 5.53 \\
\hline $\mathrm{Cr}$ & 8.17 & $\begin{array}{c}<\text { limit of } \\
\text { determination }\end{array}$ & 0.42 & $\begin{array}{c}<\text { limit of } \\
\text { determination }\end{array}$ \\
\hline $\mathrm{V}$ & 23.70 & 2.16 & 2.53 & 1.81 \\
\hline $\mathrm{Co}$ & 6.83 & 0.05 & 0.22 & 0.17 \\
\hline $\mathrm{Ni}$ & 7.94 & $<$ limit of & & 1.85 \\
\hline $\mathrm{Cu}$ & 27.00 & 2.53 & 5.23 & 0.04 \\
\hline $\mathrm{Zn}$ & 39.28 & 6.20 & 15.21 & 3.63 \\
\hline $\mathrm{As}$ & 0.65 & 0.27 & 0.40 & 0.18 \\
\hline $\mathrm{Pb}$ & 1.04 & 1.34 & 0.25 & 0.13 \\
\hline $\mathrm{Cd}$ & 0.63 & 0.07 & 0.02 & 0.19 \\
\hline $\mathrm{Se}$ & 0.52 & 0.61 & 0.59 & 3.39 \\
\hline $\mathrm{Fe}$ & 322.67 & 19.63 & 44.60 & 48.50 \\
\hline $\mathrm{Sr}$ & 35.49 & 106.57 & 30.33 & 37.43 \\
\hline $\mathrm{Rb}$ & 10.56 & 2.12 & 8.11 & 10.33 \\
\hline
\end{tabular}

The specificity of various elements accumulation in total phytomass of the studied plants is presented in Table 2. In the total Hedysarum phytomass (aboveground + underground phytomass), $\mathrm{Cr}, \mathrm{V}, \mathrm{Co}, \mathrm{Ni}, \mathrm{Cu}, \mathrm{As}, \mathrm{Fe}$ accumulate in higher concentrations, and in Reseda phytomass - Zn, Cd, Rb and especially Se, in Gypsophila phytomass - Ca, $\mathrm{Pb}$, and $\mathrm{Sr}$. Hedysarum and Gypsophila accumulate $\mathrm{Mn}$ in equal measures, while Reseda lags behind them twice. Gypsophila accumulates an order of magnitude more $\mathrm{Pb}$ than Hedysarum and Reseda. In the total phytomass of Reseda, $\mathrm{Cd}$ and $\mathrm{Se}$ also exceed the 
indices of Hedysarum and Gypsophila by an order of magnitude. The content of Se in Reseda is an order of magnitude higher than the regional clarke of herbaceous species (Tables 1 and 2). Gypsophila is twice higher than Reseda and Hedysarum accumulate Ca and Sr. It is the data on Gypsophila that determine the superiority of the studied species in the accumulation of these two elements in comparison with the herbaceous species of the region (Table 2).

Table 2. The average content of the analyzed elements in the total phytomass of Hedysarum grandiflorum, Reseda lutea, Gypsophila jusepczukii

\begin{tabular}{|c|c|c|c|}
\hline $\begin{array}{c}\text { Chemical } \\
\text { elements }\end{array}$ & $\begin{array}{c}\text { Hedysarum } \\
\text { grandiflorum }\end{array}$ & Reseda lutea & $\begin{array}{c}\text { Gypsophila } \\
\text { jusepczukii }\end{array}$ \\
\hline $\mathrm{Ca}$ & 11314.00 & 12858.25 & 22008.00 \\
\hline $\mathrm{Mn}$ & 15.11 & 6.31 & 15.17 \\
\hline $\mathrm{Cr}$ & 1.12 & 0.00 & 0.00 \\
\hline $\mathrm{V}$ & 2.55 & 2.04 & 2.49 \\
\hline $\mathrm{Co}$ & 0.28 & 0.17 & 0.10 \\
\hline $\mathrm{Ni}$ & 3.31 & 0.94 & 0.00 \\
\hline $\mathrm{Cu}$ & 5.61 & 4.59 & 2.82 \\
\hline $\mathrm{Zn}$ & 16.56 & 29.32 & 9.05 \\
\hline $\mathrm{As}$ & 0.53 & 0.23 & 0.33 \\
\hline $\mathrm{Pb}$ & 0.32 & 0.13 & 1.09 \\
\hline $\mathrm{Cd}$ & 0.02 & 0.15 & 0.08 \\
\hline $\mathrm{Se}$ & 0.63 & 3.12 & 0.79 \\
\hline $\mathrm{Fe}$ & 88.02 & 47.32 & 57.50 \\
\hline $\mathrm{Sr}$ & 46.65 & 39.05 & 106.72 \\
\hline $\mathrm{Rb}$ & 7.59 & 12.54 & 2.92 \\
\hline
\end{tabular}

The revealed features are very clearly confirmed by the "fingerprints of plants" method, the essence of which is to visualize the features of chemical elements accumulation in phytomass of various species when compared with the indicators calculated using the data for a significant species number (so-called "Reference Plant" indices), proposed by B. Markert [9] and used in relation to various plant species [10]. In essence, this method is a further development of the classical approach, which involves comparing the indicators of individual species with averaged values obtained by generalizing the indicators of many species of a certain territory. In this case, positive or negative deviations from the indicators of the "reference plant" in \% are used to construct histograms [10].

A visual display of our results using this approach is shown in Fig. 1-3. Thus, the most noticeable features distinguishing the fingerprints of obligate calciphyte Gypsophila are a sharply increased accumulation of $\mathrm{Pb}$ in stems, a high accumulation of $\mathrm{St}$ in stems, leaves, and flowers, as well as an increased accumulation of $\mathrm{Ca}$ in stems and flowers, but not in the leaf mass, and a slightly increased accumulation of Se in stems (Fig. 1). At the same time, for the 10 remaining chemical elements, which were determined in the aboveground organs phytomass, the content was reduced, which is quite consistent with their lower availability in soils formed on rocks saturated with calcium.

For the calciphilic species Hedysarum, which is able to inhabit outside the calcareous substrates, the content of almost all analyzed elements was reduced, which was shown to the least extent for $\mathrm{Ca}, \mathrm{Sr}$, and $\mathrm{Rb}$. Only the content of $\mathrm{Se}$ in leaves was increased in comparison with the reference phytomass indices (Fig. 2). 


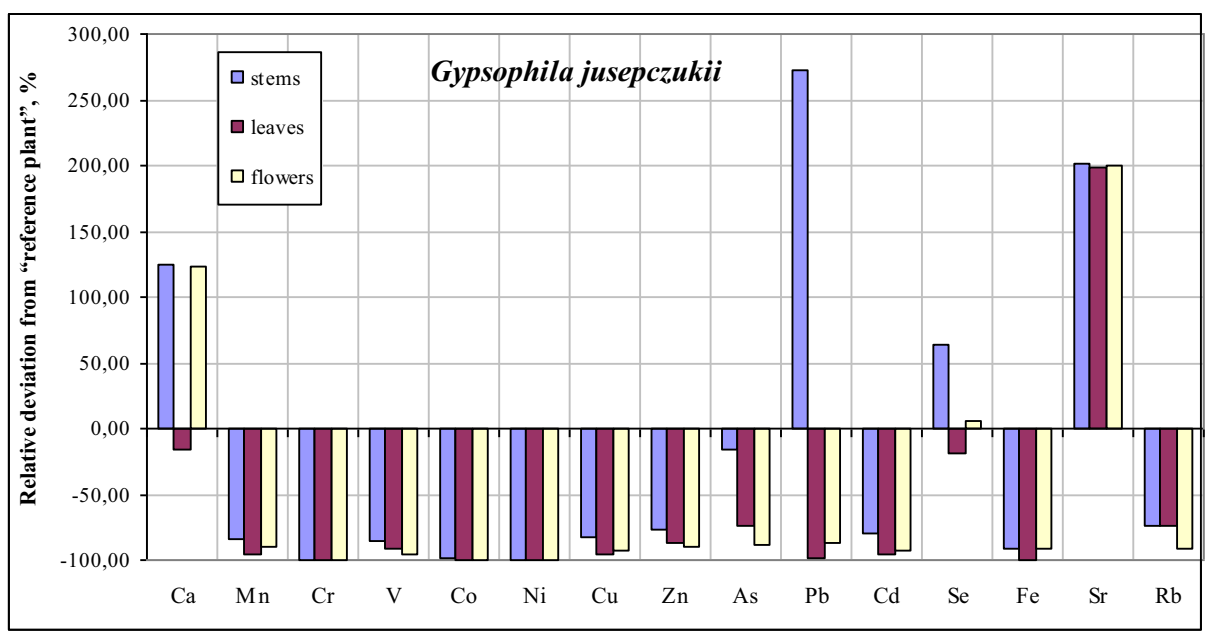

Fig. 1. Indicator "fingerprints" for calcephyte Gypsophila jusepczukii

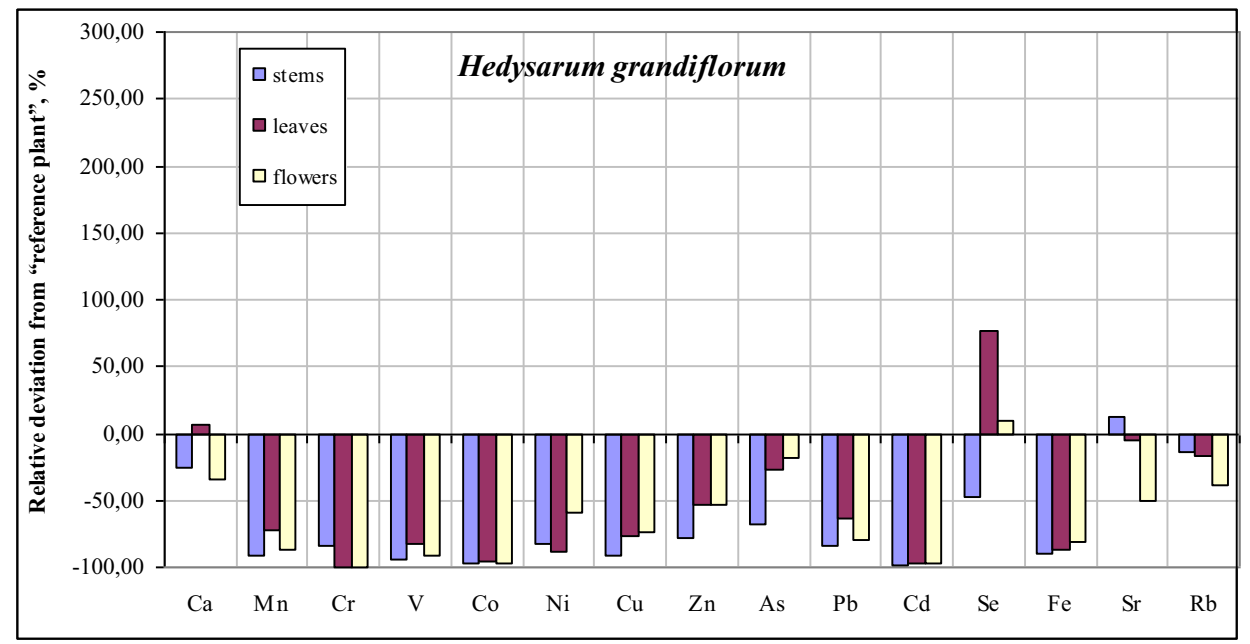

Fig. 2. Indicator "fingerprints" for calcephilus Hedysarum grandiflorum

Reseda lutea, which successfully uses various growing conditions, found an extremely high accumulation of Se in the stems, leaves, and flowers in the biotope of calcareous outcrops. Only for stems phytomass the accumulation of $\mathrm{Sr}$ was increased, the same to $\mathrm{Ca}$, and to a lesser extent - Rb. This species, in comparison with the two considered, was characterized by a relatively higher level of $\mathrm{Zn}$ and $\mathrm{Cd}$, which did not reach the reference level. The fact of high accumulation of Se in Reseda phytomass requires additional study in samples that should be collected in other soil conditions. This will make it possible to establish is this biogeochemical feature typical for the species (Fig. 3).

The analysis of the diagrams confirms the conclusion about the less active accumulation of most of the analyzed elements by plant species growing on chalk substrate, compared to herbaceous plants of common meadow and steppe habitats of the region. This conclusion is objective both for the total phytomass of the studied plants (Table 1) and for their individual organs (Fig. 1-3).

Comparison of the absolute values of the chemical elements content in individual organs of studied species also shows their specificity. 


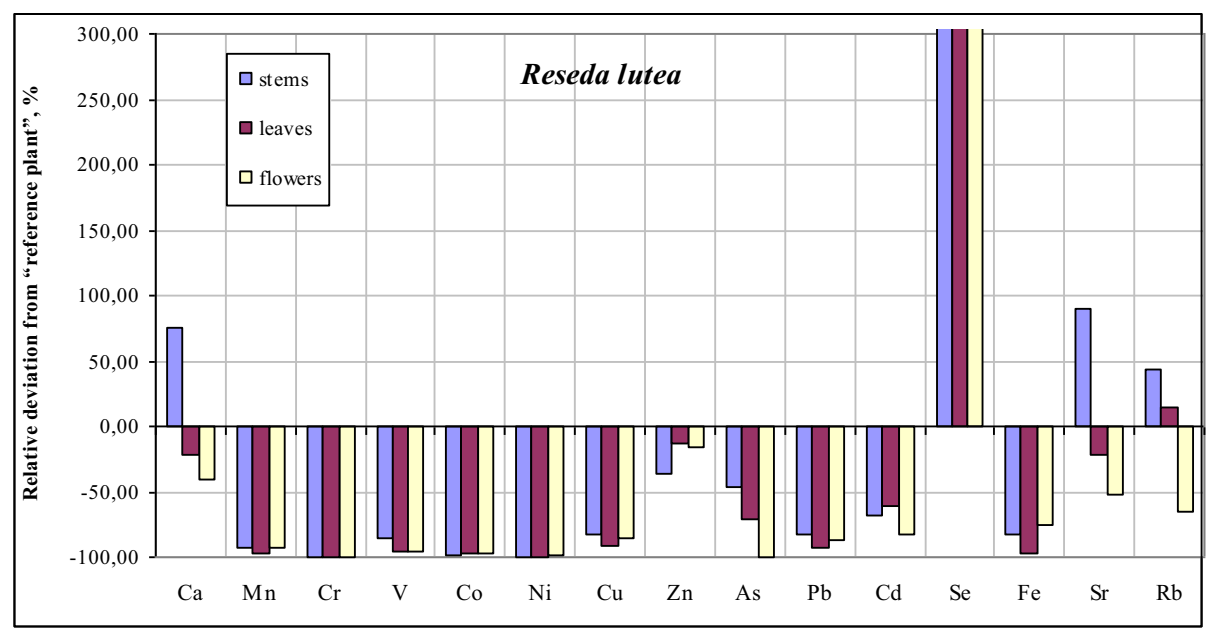

Fig.3. Indicator "fingerprints" for Reseda lutea

For Hedysarum and Gypsophila, a more significant accumulation of most elements in the roots, which exhibit barrier functions in relation to these elements, was clearly manifested. So, in the roots of Hedysarum there is an accumulation of $\mathrm{Ca}, \mathrm{Cr}, \mathrm{Co}, \mathrm{Ni}, \mathrm{Cu}$, $\mathrm{Zn}, \mathrm{As}, \mathrm{Pb}, \mathrm{Cd}, \mathrm{Fe}, \mathrm{Sr}$, and in the roots of Gypsophila - $\mathrm{Ca}, \mathrm{Mn}, \mathrm{V}, \mathrm{Co}, \mathrm{Zn}, \mathrm{As}, \mathrm{Cd}, \mathrm{Se}, \mathrm{Fe}$, $\mathrm{Sr}, \mathrm{Rb}$. In the roots of Reseda, only $\mathrm{Ni}, \mathrm{Cu}, \mathrm{As}, \mathrm{Rb}$ accumulate in higher concentrations, and most of the elements accumulate in its stems - $\mathrm{Ca}, \mathrm{Mn}, \mathrm{V}, \mathrm{As}, \mathrm{Pb}, \mathrm{Cd}, \mathrm{Se}, \mathrm{Sr}, 4$ more elements - in its flowers (Mn, Co, Zn, Fe). For Reseda and Gypsophila, a relatively weak accumulation of elements in leaves was observed. Only $\mathrm{Zn}$ in Reseda leaves and $\mathrm{Sr}$ in Gypsophila leaves differ in relatively high concentrations. Hedysarum leaves actively accumulate $\mathrm{Mn}, \mathrm{V}, \mathrm{Cu}, \mathrm{Zn}, \mathrm{Se}, \mathrm{Rb}$. An interesting feature of Gypsophila is the same and very high accumulation of $\mathrm{Sr}$ in all organs $(106.2-107.2 \mathrm{mg} / \mathrm{kg}$ ) and $\mathrm{Ca}$ in all organs $(25922.0-26192.0 \mathrm{mg} / \mathrm{kg})$, except for leaves $(9736.0 \mathrm{mg} / \mathrm{kg})$. Other investigated species do not reach similar $\mathrm{Ca}$ and $\mathrm{Sr}$ concentrations.

\section{Conclusions}

Thus, the performed studies allow us to conclude that the effective barrier function of roots in relation to most of the analyzed elements is characteristic of calciphilic (Hedysarum) and calciphytic (Gypsophila) plant species, but almost not manifested for Reseda with its wide ecological habitats amplitude. To a certain extent, the stem tissues play a barrier biogeochemical role in Reseda. A general biogeochemical feature of the species under study was revealed, which is expressed in an increased accumulation of Se in aboveground organs, which was especially pronounced for Reseda.

That is why we think it is necessary to make additional studies using Reseda phytomass formed on another soil cover. The results will make it clear whether Reseda lutea can be used as bioindicator of Se level in soils of our region.

\section{References}

1. G.Tyler, Fol. Geobot. 38, 419 (2003)

2. J. Ewaid, Fol. Geobot. 38, 357 (2003) 
3. A. Maslennikov, Flora of calcareous landscapes of Privolzhskaya Vozvyshennost (Ulianovsk, 2008) (In Russian).

4. P. A. Storh, O. L. Pescott, J. O. Mountford, Plant Ecol. 218, 1269 (2017)

5. N. Pipenbaher, M. Kaligarič, N. W. H. Mason, S. Škornik, Biodiv. Cons. 22, 2207 (2013)

6. H. Albrecht, S. Haider, Biodiv. Cons. 22, 2243 (2013)

7. H. Lambers, R. S. Oliveira, Plant Physiological Ecology. (Springer Nature Switzerland AG, 2019)

8. Qualitative chemical analysis of soils. The Method of metals content evaluation in solid bodies by method of spectrometry with inductively coupled plasma (Moskow, Center of Water Investigation and Control, 2005) (In Russian)

9. B. Markert, Wat., Air and Soil Pollut. 64, 533 (1992)

10. R. Djingova, I. Kuleff, B. Markert, Ecol. Res. 19, 3 (2004) 